FACTA UNIVERSITATIS

Series: Linguistics and Literature Vol. 18, No 2, 2020, pp. 181-194

https://doi.org/10.22190/FULL2002181I

Original Scientific Paper

\title{
THE SPACE OF TRANSCULTURATION IN THOMAS KING'S GREEN GRASS, RUNNING WATER
}

\author{
UDC 821.111(71).09 King T.
}

\section{Sanja Ignjatović, Natalija Stevanović}

Faculty of Philosophy, University of Niš, Serbia

\begin{abstract}
This paper uses Thomas King's novel Green Grass, Running Water (1994) to examine the contact between two cultures in Canada; the culture of the Indigenous people and the culture of the white settlers. Taking postcolonial studies as its framework, this paper relies on works written by critics such as Stephen Slemon, Edward Said, Homi Bhabha, Gayatri Chakravorty Spivak, and others, in its analysis of the transcultural space which Thomas King creates in his novel. The four mythical stories in the novel offer a fruitful ground upon which contact between the two cultural, social and political spaces can be analyzed. We hope that the research conducted in this paper can serve as an explanation of the nature of transculturation, and in the words of Bhabha $(1994,25)$, offer a textual "space of hybridity".
\end{abstract}

Key words: Canada, First Nations, postcolonial studies, transculturation

\section{INTRODUCTION}

In this paper we discuss Thomas King's novel Green Grass, Running Water as an illustration of the discursive nature of cultural norms and practices. The paper also examines the manner in which Thomas King presents the contact and encounter between the Indigenous people of Canada and the white settlers. The paper is an attempt to explain the nature of transculturation as illustrated in the novel, and as relevant in contemporary discourse, by considering transculturation figures in the novel not as a theoretical concept, but rather as a problematizing device.

The paper draws on four mythical stories in the novel as exemplary portrayals of the contact zones, i.e. the social and political spaces where two cultures come into contact. The narratives of the Blackfoot tribe members in Green Grass, Running Water go well beyond postmodern begrudged regurgitation of historically charged issues. These are narratives grounded in the present moment, indubitably haunted by the past. In line with James $\mathrm{H}$.

Submitted May 4, 2020; Accepted November 18, 2020

Corresponding author: Sanja Ignjatović

University of Niš, Faculty of Philosophy

E-mail: sania.ignjatovic@gmail.com 
Cox's $(2000,231)$ perspective on the technical, formal, and symbolic importance of intertextuality in "All This Water Imagery Must Mean Something: Thomas King's Revisions of Narratives of Domination and Conquest in Green Grass, Running Water" that narratives "shift the colonial perspectives of the original texts and subsequently interrogate the cultural, political and ideological foundations of the cultures that informed their production," this paper investigates the concept of transculturation to highlight its problematizing potential in terms of socio-political and historical influences. The cosmological stories satirically reworked in the novel underscore the importance of the unvoiced perspective, and represent a postmodern deconstruction and interrogation of the values emanated in the institutionalized discourses of history and religion.

The theoretical framework is related to the field of postcolonial studies, and draws on the idea presented by Stephen Slemon in The Scramble for Post-colonialism (2003, 45-46) that colonialism is "an ideological or discursive formation," as well as "an economic and political structure of cross-cultural domination." These concepts provide a background for the main focus of the paper. We analyze the narratives told by the four Indians, as King terms them in the novel, Hawkeye, Ishmael, Robinson Crusoe and Lone Ranger, as crucial in examining the contact and encounter between the two different cultures at the grandnarrative level - the Bible and the characters' versions of Genesis - the institutionalized practices being represented by the Western Christian ethos, on the one hand, and King's subversive rewriting of specific parts of Genesis, and their satirical interpretation, as told by the Indians to uncover broader socio-political implications. This paper argues that Green Grass, Running Water investigates a subversive space of transculturation through the brilliantly humorous and satirical narratives of the four Indians, whose interaction with Western narratives, and their respective agents, exposes the wider and relevant context of colonialist ideology as a persistent discursive practice. In those terms, Wolfgang Welsch's concept of transculturation, as expounded in his article "Transculturality - the Puzzling Form of Cultures Today" (Nordin et al. 2015, 169), is introduced as an instrument for bringing two different groups into contact, culturally or in some other way, in order to discover, display or emphasize the presence of any difference.

\section{THE INVISIBLE BLACKFOOT}

A wider interpretation of the European concept of Orientalism, and its subsequent translation in the form of the narrative of the "Other," can be observed in the treatment of Indigenous peoples on the American continent. For Said (2003, xii), the divisive concepts of the "same" and the "Other" have no "ontological stability," and yet they are perpetuated in the cultural and political discourses produced to mobilize "fear, hatred, disgust and resurgent self-pride and arrogance" (Said 2003, xii). Furthermore, the concept behind Said's Orientalism, the idea of ideological and cultural definition against the backdrop of political and economic interests extends to the question of Indigenous peoples' initial dispossession as well as their continual struggles to maintain and reconfigure their identity as a group and as individuals. Moreover, in the process, the Indigenous are often found on the scale from a historically backward, mystified, and irretrievably lost position which renounces their heritage, to that in which they possess no historical sense and merge into the global capitalist society where individuality is substituted for neo-liberal, capitalist, consumer uniformity. Both positions marginalize the human being and disregard their historical presence. In Imperial Eyes: Travel Writing and Transculturation (1992/2008), 
Pratt $(2008,7)$ notices that "subordinated or marginal groups select and invent from materials transmitted to them by a dominant or metropolitan culture". Pratt further elaborates that "[while] subjugated peoples cannot readily control what the dominant culture visits upon them, they do determine to varying extents what they absorb into their own, how they use it, and what they make it mean". Such an image, accruing layers of inscriptions throughout centuries, is essentially divisive on multiple levels. On the one hand, Indigenous space is limited to the private sphere, which implies isolation from the community, or enclosure in a limited community, such as the reserve. The Indigenous person is granted rights to engage in customary, traditional, religious and other cultural rituals and rites, in the area restricted to the reserves, as long as they are regulated by a governmental body. In The Location of Culture, Bhabha $(1994,9)$ notes "[The] recesses of the domestic space become sites of history's most intricate invasions. In that displacement, the borders between home and world become confused, and, uncannily, the private and the public become part of each other, forcing upon us a vision that is as divided as it is disorienting."

Observing the contact between two cultures from the perspective of the Indigenous people and the colonist reveals an incongruity pertaining to the "origin stories" which simply negate the existence of the Indigenous people before colonization, and therefore negate any territorial or other rights. As Lutz (2007, 1) suggests in Myth and Memory: Rethinking Stories of Indigenous-European Contact, for indigenous peoples, those stories are necessarily the "prologue to their world having been turned over".

In the case of Canada, as Ashcroft $(2007,98)$ claims in Post-colonial Studies: The Key Concepts, the indigenous people are known as the First Nations people, a community officially recognized as an administrative unit by the federal government . The federal government in Canada, since its inception, has striven to maintain a "fiduciary" relationship with Indigenous people, which started with the creation of the Indian Act in 1876. This resulted in a discriminatory act, despite positive connotations, since it recognized women and children as dependents of men, and also excluded many tribes from the document, according to McMillan and Yellowhorn in First Peoples in Canada (2004, 4). In his book, A Short History of Canada, Morton comments very briefly on the unspecified or implied grievances of the First Nations peoples from the obvious perspective of the European colonists. According to Morton (1997, 26), "[in] the legend of Canadien survival, there was little room for sympathy with the Indians, caught between powerful European rivals and struggling with their own ingenuity and courage to defend their interests". The irony is intensified further considering the fact that the short overview of Canadian colonial and postcolonial history deals with the issue of genocide, segregation and racial discrimination only in terms of their possible political and economic necessity. Morton, perhaps inadvertently, discusses the matter of Indigenous dispossession in his study as a matter belonging to the past, and refuses to elaborate on the nature of the colonial attitude towards the Indigenous people. This refusal to acknowledge the detrimental impact of the colonial atrocities which continue to affect the Indigenous people renders the matter of discussing them all the more relevant in contemporaneity.

The manner in which a historian like Morton deals with the disturbing legacy of colonial Canada relates to what Spivak (1999, 1), in A Critique of Postcolonial Reason (1999), describes as a perpetuation of colonialism in terms of the production and transmission of neocolonial knowledge by placing colonialism in the past. This neocolonial discourse locates purposefully whatever the dominant discourse considers problematic with regard to the colonized and dispossessed "Other" in the past, while it disregards the conditions of the present, or any vision of the future. The Indigenous people either hold a subordinate or passive position in the discourse of power, shaped by the political, economic and cultural circumstance of the 
present moment. Thomas King brilliantly demonstrates that intertextuality is in itself a completely new level of transculturation because it creates a transcultural space and problematizes that space by weaving into it Western narratives through the perspective of the Indigenous people. This paper aims to illustrate how this tension between the dominant and subordinate, marginal discourses presents itself in Green Grass, Running Water.

Following this line of thought, a reference to $\operatorname{Spivak}(1999,4)$ seems necessary. This author holds that the critic introduces the concept of the "foreclosed" "native informant," an entity that is supposed to be merely unread, which is what King achieves to subvert in blending the space that the dominant culture occupies and interrogating it using intertextual references, but also examining those references through different focalizing positions. By interrogating the space that the dominant culture occupies using subversive intertextual references, King achieves a restoration of the position of the "native informant" in Green Grass, Running Water. The term "foreclosure", borrowed from Lacan, or indirectly from Freud, is used by Spivak to describe the ethical core, balancing out the dominant colonial ideology, contained within the text even when the representation of the native informant is somehow rendered invisible by the narrative discourse. Spivak perceives the native informant as a voice which may be imperceptible at first, but which provides the ethical foundation of the text. Spivak $(1999,5)$ explains further this particular term as "a name that carries the inaugurating effect of being human". In brief, Spivak's $(1999,112)$ take on the ethnographic terminology, "the native informant," is employed as "figure in literary representation." The tension contained in the figure of the native informant reflects the colonizer as the subject, and the "other," created in opposition to define the position of the informant as "the same" (Spivak 1999, 113).

In Green Grass, Running Water, the storytellers, four Indians, restore their identity by re-instating their original names in the mythical tales. The four Indians, as women, play the role of the native informant and examine the historically distorted religious and sociopolitical Western discourse. This involves vilification and negative representation of the Indigenous culture in mainstream discourse, or the distortion enforced by the imagery produced by history books, the media, popular culture, colonial and postcolonial, victim and native literatures, as highlighted in the rewritten and modified narratives of Genesis and colonial history in King's novel.

\section{THE Transcultural CONTACT}

The cosmological stories in Green Grass, Running Water can be interpreted as stories of contact, which reveal the artificiality of cultural and political practices. At the level of narration, this artificiality is exposed by a trickster deity as the focalizing subject, but also as a heterodiegetic, authorial voice, and through various focalizing characters' voices, in a concoction problematizing Indigenous and Judeo-Christian mythology, Western popculture, and literary characters. Being witty and humorous, Thomas King's introduction of the four Indians of indeterminate gender echoes the Biblical images of the four horsemen of the apocalypse, whose objective is to "fix the world," which represents a trickster reversal which subversively establishes a counter-narrative. Brilliantly woven, the novel seamlessly transitions between cosmology, mythology and something amusing, but satirical rendition of the religious narratives the Western ethos is based on. In "The Bounded Text," Kristeva sees the notion of such "permutation(s) of texts," where, within the space of a "given text", utterances are taken from other texts and intersected with one another, as intertextuality $(1941,36)$. 
In that sense, the novel connects Western and Indigenous cultures, and respective literary artefacts, to the extent of blurring the lines which have been highlighted through history, and which have been utilized politically as the motive for the conflict between the two, thus creating a new contact zone. Ashcroft $(2007,48)$ defines "contact zone" as a social space in which distinct cultures clash and interact, but with asymmetrical distribution of dominance and subordination, as usually happens in the cases of colonialism, slavery or their aftermaths. In The Location of Culture, Bhabha $(1994,34)$ explanation of the concept of cultural difference as the problem of uncertainty of cultural authority also points to cultural supremacy in the context of the differentiation between two cultures and the unequal distribution of cultural authority.

King's Green Grass, Running Water abounds in aggressive vitality in the form of the four gender-ambiguous Indians, immortal or symbolically timeless, who attempt to fix the world by triggering a natural disaster. This destructive power exerted on the world threatened by the colonist allows the Indigenous not only to retrieve the land appropriated by the oppressor, but to re-establish a connection with their own heritage. The narrative situation in the novel is such that the Indigenous right to land and the community's means to survival are called into question. Additionally, the Indigenous are placed in a position where both affiliation with the colonial culture and the refusal to abide by the new rules pull them into the discourse of the oppressor led by "a single and monolithic originating intention within colonialism, the intention of colonialist power to possess the terrain of its Others" (Slemon 2003, 48). The title, Green Grass, Running Water, underscores territorial issues, but King manages to put those into a hybrid historical, ideological, and ecological perspective, on the one hand, and into a personal perspective, on the other. Actually, King, much like Fanon in The Wretched of the Earth (2004), draws on the idea that one's freedom must first be geographically tenable. For Fanon $(2004,9)$, land is the primary source of dignity and a prerequisite for the colonized to be able to overcome the violence and the arrogance of the colonizers. For King, and for his Indians, territorial issues are also a matter of sovereignty, dignity, and survival.

\section{The Transcultural Space as the Native Space}

Green Grass, Running Water features the narratives of the four Indians as a series of cosmological stories retelling the Western and Christian story of Genesis, entangled with the novel's real-world narratives. The sensibility of the narrative, visibly postmodern and metafictional, focused on the liminal and ambivalent, relates a satirical rendition of totalizing narratives by relating ironically their unsustainability and inappropriateness in contemporaneity, by revealing the hypocrisy behind the narrative and its social and political practice, and most importantly, by exposing the artifice of narratives in general. The pastiche-like elements in the novel intensify the satirical effect which arises from the conflicts between traditions. They also complement the intertextual dimension emphasizing the complex relationship between these "opposed" narratives in the transcultural space.

The "origins" sections in the novel represent the narratives of four polymorphous Indians who relate their own versions of the narrative which in the Christian tradition has a single version. In its cyclical construction, the satirical cosmological takes on the story of Genesis told by the characters who appear in the novel's real-world. The Lone Ranger, Ishmael, Robinson Crusoe, and Hawkeye, are not only named after Western popular culture icons, but strongly suggest a colonial discourse in their popularized relationships with the Indians: Tonto, Queequeg, Friday, and Chingachgook, respectively; or First, Changing, Thought, and Old Woman, as characters who feature the Indigenous version of these cosmological 
narratives. At the same time, they serve interchangeably with the popular culture manifestations in male form. Each of the female characters who appear in the narrated versions of the cosmological story encounter relevant characters from the Bible: Ahdamn, Noah, A. A. Gabriel, and Young Man Walking on Water, whose roles, however, are exposed straightforwardly in the transcultural space created by King's trickster narrators. It is in this satirical intertextuality which goes beyond mere pastiche that King manages to reconfigure an inclusive transcultural design, by exposing the problematic nature of totalizing narratives, the discursive nature of reality, and ultimately the issue of grand-narrative artifice. King's narrative is essentially metafictional, and allows the artifice of the narrative process to surface and to indicate its ties with the discourses preceding it. As for the historically fragmented and distorted Indigenous culture in the colonial discourse, this metafictional quality hybridizes the existing narratives' vital aspects exposing the problematic nature of such stories' institutionalization. Bhabha's $(1994,2)$ comment, in The Location of Culture, on cultural differences appropriated by the discourse to deprive minorities of their own space may support as he finds that the "representation of difference must not be hastily read as the reflection of pre-given ethnic or cultural traits set in the fixed tablet of tradition," but that "the social articulation of difference, from the minority perspective, is a complex, on-going negotiation that seeks to authorize cultural hybridities that emerge in moments of historical transformation."

Thomas King's almost whimsical calamity which befalls the story-world, i.e. the novel real world, can be understood as a symbolic substitute for political transformation. Ironically, this catastrophe comes in the form of a flood, reminiscent of the Old Testament Biblical deluge staged with the purpose of purifying a corrupt world created by an apparently outraged Christian god. Moreover, the motif of water and its uncontrollable power features the cosmological version, establishing a contrast between the Christian conception of Genesis and the Indigenous myths, and the Christian institutionalized and internalized constructs in the mainstream discourse. The irony, of course, extends to Indigenous mythology, in which occurrences like natural disasters happen by mistake or due to the carelessness of Coyote, the trickster deity. Particularly subversive in the re-interpretation and re-working of Judeo-Christian myths in the form of Indigenous oral tradition is the uncovering of the nature of contrivance contained within these myths and in the Western ethos. This highlights the absurdity of the institutionalized grand narratives, which permeate the dominant discourse.

The very act of re-appropriating grand narratives which King's shape-shifting character-narrators attempt to achieve happens from a "less privileged cultural, ideological and narrative space" (Cox 2000, 223), in Spivak's terms, the position of the "native informant." This position is subversive precisely because it comes from both within and without the dominant culture and discourse. This re-appropriation represents an act of reevaluation of both Indigenous and dominant culture; briefly, the creation of a transcultural and inclusive space. Such merging of cross-cultural spaces can be understood best in light of the concept called "transculturality," according to Welsch, who sees "transculturation" as a process by which the meeting of two different or opposing groups with a different cultural background may lead to the blurring of cultural boundaries (Nordin et al. 2015, $169)$. Welsch $(1999,202)$ does not see transculturality as an outcome which is essentially separatist, exclusive, or as leading to uniformity; rather, the transcultural is meant to raise our awareness of the Other, and to allow diversity to emerge. In addition, by obliterating the boundaries of cross-cultural myths with a satirical insistence on intertextuality, King unapologetically reveals the senselessness of the notion of a single, fixed grand narrative. By merging cultural spaces and their respective socio-political manifestations in the novel's real-world, King's irony engages the tension of intentionally paralleled figures 
from the Judeo-Christian and Indigenous traditions and mythologies effortlessly, as well as from popular culture and literature, who play the game of telling the "right story."

It is the postmodern, self-reflexive and metafictional nature of the narration in the novel which almost imperceptibly allows for the introduction of the $I$ entity in the story, which can be read as a thread connecting the two cultural spaces. This $I$ entity, occupying the position of the omniscient, although heterodiegetic narrator, signals the postmodern, deconstructive approach to the concept of narrative itself. It allows for the interpretation of its very presence in the story as an indication of the discursive nature of the reality of the novel on both the cosmological and the real-world level. By extension, King's authorial and metafictional intrusion comments on the illusory nature of the institutionalization of such, or any other narratives. Additionally, the differences in narration at the formal level, i.e. the versions of Genesis in the form of oral literature as opposed to the novel's realworld narration following genre conventions, broaden the critique on the closure of grand narratives, or their fixedness. The transcultural "grand narrative architect" interpenetrates other narratives and resembles Spivak's foreclosed Indigenous informant. This voice, although not necessarily emphasized, serves both the purpose of counteracting the storytelling process itself and foregrounding the postmodern interrogative quality of the novel. Additionally, it is also a corrective voice. This $I$, as an omnipresent entity, may be considered another contact zone where many complex encounters regarding the narrative happen (Ashcroft 2007, 49). It serves another purpose, that of transculturality, enabling the creation of the space of hybridization: the point at which there is a cultural transfer, an exchange and blending of cultures (Nordin et al. 2015, 123).

\section{THE SATIRE OF GENESIS}

In First Peoples in Canada (2004), McMillan and Yellowhorn (2004, 3) suggest that "[e]very narrative benefits from the presence of intriguing characters whose actions move the story along". In those terms, King provides a series of intertextual interactions where the satirical nature of conflict, exposed in its incongruity and unsustainability, moves the "story of origins" beyond the institutionalized cultural space of the Western ethos. As Donaldson $(1995,34)$ explains in "Noah Meets Old Coyote, or Singing in the Rain: Intertextuality in Thomas King's Green Grass, Running Water," by "borrowing eclectically from many different traditions, King creates his own distinctly hybrid [...] intertextual vision". King's use of "travelling characters" does not "subjugate or obliterate," but rather "parodies and resists the way dominant Christian stories have too often been used" (Donaldson 1995, 34). In this manner, King does not only emphasize the constructedness of these intertextual references, but emphasizes their predilection to change. More specifically, by creating a space in which different traditions are set against each other, King allows for the Indigenous narratives to evolve into revised structures.

In the cosmological narrative featuring First Woman, the Lone Ranger in the inbetween space and the novel real world, King re-examines the story of the Garden of Eden and Eve's Fall by introducing the character of Ahdamn, a brilliant pun on the Biblical message of the exodus, which promotes misogyny and exonerates Ahdamn. This particular story also features the character of the talking Tree that First Woman bumps into and who/which offers fruit to her. Adding to the humorous effect, the Judeo-Christian god resentfully comments on the blasphemous world Coyote has supposedly created: 
So. There is that garden. And there is First Woman and Ahdamn. And there are the animals and the plants and all their relations. And there is all that food.

"Boy," says Coyote, "that food certainly smells good."

They can't eat my stuff, says that GOD. And that one jumps into the garden.

Oh, oh, says First Woman when she sees that GOD land in her garden. Just when we were getting things organized. (King 1994, 41)

In the context of the European emigrants being aided by Indigenous North Americans in order to survive, and subsequently appropriating their land and forcing them into exile, King's first version of Genesis unapologetically exposes the Christian insistence on the primacy of "GOD" as an episodic character. As Bailey $(1999,43)$ points out in "The Arbitrary Nature of the Story: Poking Fun at Oral and Written Authority in Thomas King's Green Grass, Running Water," the inherent belief in Christian myths is that "[...] its precepts are true, not only for members of its own faith but for all people, regardless of whether these people have been initiated to this truth or whether they accept it". It is significant that in King's version of Genesis, he subversively places GOD after the beginning of creation (Bailey 1999, 43). This part of the novel also explains that GOD was actually created when Coyote was dreaming, and one of those dreams got loose, and eventually proclaimed that it was "in charge of the world" (King 1994, 1). The juxtaposition of the characters belonging to cross-cultural myths allows for the voice of the foreclosed "native informant," captured in the consciousness of the $I$ entity, to self-consciously remind the characters, and itself, of the artifice of narration; "'[that's] what happens when you don't pay attention to what you're doing,' I says” (King 1994, 69).

The dialogue form, supported by the omniscient narrator's eyes on the situation, and the implied author's occasional intrusions, escapes any didactic or instructive tone, since it presents the situation in an unprocessed form. The reader is interpellated, required to give their own value judgment on the collision of myths in a historically and culturally imbued context. Much in the vein of Spivak's elaboration of the role of the foreclosed Indigenous informant, the reader's affect is reactivated by the satirical content:

What a stingy person, says First Woman, and that one packs her bags. Lots of nice places to live, she says to Ahdamn. No point in having a grouchy GOD for a neighbor.

And First Woman and Ahdamn leave the garden.

All the animals leave the garden.

Maybe I'll leave a little later, says Old Coyote.

You can't leave my garden, that GOD says to First Woman. You can't leave because I'm kicking you out. (King 1994, 69)

The twist where First Woman decides to leave the garden, as opposed to being "kicked out," leads the couple into situations which, charged with stereotypical representations of Indians in colonial discourse and popular culture, force First Woman to mask herself in order to save their lives. In her form of the Lone Ranger, with Ahdamn's transformation into Tonto, the couple attains temporary freedom since the rangers gallop off, "looking for Indians and buffalo and poor people and other good things to kill" (King 1994, 71).

However, the deception which saves First Woman and Ahdamn from the rangers is soon found useless, for they are arrested by soldiers, charged with being Indian and taken 
to Miami, Florida, on a train with "a bunch of Indians on that train with chains on their legs" (King 1994, 99). On the train, killing time as if it were an adventure, naïve Ahdamn starts drawing pictures of a buffalo, a horse, and a refrigerator, and becomes "famous" (King 1994, 100). The story echoes the scene from the very beginning of the novel when the character of Alberta Frank recounts the events of 1874, and the US Army "campaign of destruction aimed at forcing the southern Plains tribes onto reservations" (King 1994, 18), connecting the timeless cosmological narrative to the novel's real-world. Alberta Frank, an Indian History university professor, recounts how seventy-two Natives were taken to Fort Marion for charges unknown except for their race and ethnicity, and for the possibility that they might be involved in the war against colonial forces. Imprisoned, and left to their own devices, some twenty-six of the Indians drew pictures collectively called the Plains Indian Ledger Art (King 1994, 19). The only female prisoner at Fort Marion, a wife of one of the prisoners, creates a direct link to the narrative of First Woman, an allegorical reference to the historical account. In the case of transcultural exchanges, Ahdamn is quite comfortable in the hybridized place, even though it is a prison, while First Woman refuses so, puts on a mask of the Lone Ranger, and walks to the front gate (King 1994, 100). This act creates another transcultural connection by appropriating a face that belongs to the culture of the oppressor in a dynamic and rebellious manner.

First Woman's escape from Fort Marion forces Coyote and the I entity to urge Ishmael to tell the story of Changing Woman more carefully as the one who falls from the edge of the sky and lands on the soft Old Coyote. At this point, the I-narrating entity, or the implied author, becomes more involved in the dialogues and takes a stronger position in guiding the narrative. Changing Woman, much in the vein of the story told by the Lone Ranger, has an encounter with a Biblical figure, and this time it is Noah, or "a little man with a filthy beard" (King 1994, 145), in a canoe, surrounded by animals. He demands information on whether Changing Woman is related to Eve who sinned in any way. Colonialism did not only introduce cultural changes, but it also brought religious influences which spread together with the trade contacts (McMillan and Yellowhorn 2004, 52); this encounter with Noah serves also as a transcultural blending of two different traditions (Nordin et al. 2015, 123). Changing Woman's liberal or unusual behavior in the form of communicating directly with Old Coyote invites Noah to establish authority and boundaries to teach her about patriarchy. This character is quick to explain that on his Christian ship animals do not talk, since there are rules (King 1994, 145). Incidentally, the mere presence of Changing Woman is understood by this version of the Biblical character as a gift he is to receive and possess.

In talking to the animals on Noah's canoe, Changing Woman learns about Christian rules, and how Noah threw his wife and children into the water in order to save the animals. Eventually, Changing Woman manages to evade Noah's comical sexual advances, made with the intention to procreate and populate. Noah and the animals leave, and Changing Woman is left stranded on an island until she finally hears the voice of Ahab, "a short little man with a wooden leg" (King 1994, 194). When Changing Woman introduces herself, Ahab sees her as a young man, and insists on calling her something other than Ishmael the name she tells him. Changing Woman or Ishmael, after accepting the name Ahab insists on, i.e. Queequeg, finds herself on a whaling ship. As with First Woman's narrative, Changing Woman shape-shifts from an Indigenous into a popular culture character; this time, however, it is she who becomes the subdued side-kick, a South-Sea islander, Queequeg, in the same manner in which Ahdamn becomes Tonto. In the events that follow, the two of them become an involuntary part of the crew seeking "the great male white 
whale" (King 1994, 196). Changing Woman "interrupts the power of dominant cultures to enforce meaning" (Donaldson 1995, 38), by claiming that what they are actually after is a black lesbian whale, Moby-Jane and not Moby-Dick:

"She means Moby-Dick," says Coyote. "Iread the book. It's Moby-Dick, the great white whale who destroys the Pequod."

"You haven't been reading your history," I tell Coyote. "It's English colonists who destroy the Pequots." (King 1994, 196)

In a perfect example of pastiche creating grounds for hybridity, King's Changing Woman exposes another aspect of the transcultural encounter (Nordin et al. 2015, 11), not only patriarchy deeply engraved in Christian Biblical stories, but their sinister manifestations in the form of racism and misogyny. The Changing Woman's story features a black lesbian whale whose performative is bound by the Christian racial, ethnical, and gender norm. At the same time, King's own interpretation of the performatives stands to contradict the established patriarchal norm, and at the level of the cosmological in the novel-real world, it allows for the fluidity, which the real-world, referential, mainstream discourse and other discourses related to it do not tolerate. The four Indians are both female and male; they are characters from popular culture and emanations of the enslaved Indians. By making use not only of the Biblical stories, but also of the Anglo-American literary works with their somewhat ambiguous representation of Indians, King creates a hybrid space which allows for the intertextual exchanges to take place. In this hybrid space, the four Indians represent everyone; they live in an intertextual, transcultural space where they encounter the literary representatives of the Western world, which further allows King's authorial intrusions to uncover masterfully the racist legacy of the Western literary canon through their encounter. At the same time, King relates this to the extermination of Indigenous peoples by "borrowing" the metaphor of the whale-hunt from the novel Moby-Dick (1851) by Herman Melville, in which the animal stands for Nature, as something that has to be subjugated. Equally prominently, King manages to bring into focus one's sexual orientation as a basis for marginalization and exclusion. The metaphor of Moby-Dick as a black lesbian, which normally has no place in the discourse, for she is politically, economically, and culturally invisible, becomes Moby-Jane, the black female whale who entices Ahab to sacrifice his entire crew. Just like First Woman, Changing Woman is taken to Florida, but before that Moby-Jane takes her "someplace warm" (King 1994, 197). In fact, Moby-Jane and Changing Woman spend weeks in what looks to be a romantic or sexual relationship. However, when they finally reach land and say their goodbyes, for Moby-Jane needs to go back and sink Ahab's ship again, Changing Woman is distracted enough not to see soldiers coming, and is dragged to Fort Marion.

After the story of Changing Woman ends with her imprisonment, Robinson Crusoe takes his turn to tell the story, featuring Thought Woman. This time, she floats in the ocean for a long period of time, and floats ashore only to find a curious little man, A. A. Gabriel, a member of the Canadian Security and Intelligence Service, or Heavenly Host (King 1994, 269). Namely, Thought Woman encounters a representative of Canadian institutions whose business card sings not the national anthem, but evocative of the injustices against the Indigenous people. The sardonic undertone of the otherwise satirical dialogue between the Indian and the representative of the State exposes the responsibility of the Church apparatus in working with the colonial government, the religious narrative institutionalized and therefore manifest in the socio-political treatment of the marginalized, the enslaved and subdued. Another narrator, Coyote, sees the similarity between the national anthem of 
Canada and the "Hasanna da" chant. Coyote, who is a trickster above all, seemingly naïve but perceptive, mixes the lyrics with the chant when singing the national anthem, which results in "our home on Native's land" (King 1994, 270). What Thought Woman experiences when reaching land resembles the procedure immigrants go through at customs: they ask for her Social Insurance Number, and ask some personal and intimate questions:

Virgin verification form, says A. A. Gabriel. Here's a map of the city. We're here, and this is where you'll have the baby.

Hosanna da, hosanna da, sings that Card. Hosanna da.

I'm not pregnant, says Thought Woman.

No problem, says A. A. Gabriel. Sign this paper.

As long as the grass is green and the waters run, says that White Paper in a nice, deep voice.

Oops, says A. A. Gabriel, and he shoves that White Paper back into the briefcase. Wrong paper, he says. That one is for later. (King 1994, 270-271)

Just as Thought Woman refuses to acknowledge the validity of bureaucratic matters when interrogated by A. A. Gabriel, she refuses to convert to Christianity, or to recognize the validity of the proposition by Heavenly Host - Gabriel. The name of the person in charge of her being admitted to Canada is suggestive of the strong relationship between Church and State, for this person has two functions, i.e. to initiate newcomers bureaucratically and to ensure that they adhere to a single religious apparatus. Furthermore, King's obviously feminist commentary on Coyote's and Gabriel's confusion at her refusal to abide by the rules reveals that general discourse does not grant women a choice: "So she really means yes, right?" Coyote asks the I entity. A. A. Gabriel asks Thought Woman the exact same question: "No, says Thought Woman" (King 1994, 271).

Besides being denied freedom of choice, Thought Woman is informed that noncompliance and disobedience equal social exclusion, that is they "can always find another one" since "there are lots of Marys in the world" (King 1994, 272). The echo of the name "Mary" adds to the irony of every woman's position, but also the hypocritical incongruity behind the cult of Mary in patriarchy. After running away from A. A. Gabriel, Heavenly Host, Thought Woman becomes stranded on an island where she meets the shipwrecked writer, Robinson Crusoe. King's allusions to Shakespeare's The Tempest become obvious when Coyote mentions Caliban. The satire gains momentum when Robinson Crusoe wants to call Friday Caliban. Humorously, Thought Woman and Robinson Crusoe, although doubles, react differently to the sight of the Indian. Robinson Crusoe "as a civilized white man" desires "[...] someone of color around whom [he] could educate and protect" (King 1994, 294). Thought Woman serves to expose the power relations which Robinson Crusoe establishes by offering to change roles: "Sure, says Thought Woman, I'll be Robinson Crusoe. You can be Friday" (King 1994, 295). The dialogue between the two is a parody of the discourse between an Indian and an entitled white male, i.e. the colonizer. Robinson Crusoe's "attempt to dominate in the name of a cultural supremacy," is something that Bhabha $(1994,34)$ perceives to come into being "only in the moment of differentiation". Finally, like First Woman and Changing Woman, Thought Woman is also captured by the soldiers in Florida. 
As already mentioned, numerous figures from Western narrative, biblical or cultural, attempt to control women by invoking rules, convinced that the women will heed (Bailey 1999, 47). The Western literary narrative is imbued with stories from the Bible, and thus, in order to create a proper hybrid space in which the intertextual aspects of both the Indigenous and the Western cultures are included, King transculturates these myths as well. Hence, in Hawkeye's version of the story, Jesus Christ features as Old Woman's double, a Young Man Walking On Water, who immediately informs her of the Christian rules:

And the first rule is that no one can help me. The second rule is that no one can tell me anything. Third, no one is allowed to be in two places at once. Except me. (King 1994, 350)

Old Woman notices that Jesus is trying to help men, threatened by rising waves, stuck in a boat. However, following Christian rules, Jesus remains impotent in the face of the danger and refuses Old Woman's help. Uninvited, Old Woman sings songs to the waves, which eventually calms the waters down. However, the men cannot accept a woman as their savior, refuse to believe they have witnessed a miracle and decide it is "better to follow him around" (King 1994, 352). After floating for a while, Old Woman meets "a skinny guy" (King 1994, 392), Nathaniel Bumppo, the Post-Colonial Wilderness Guide and Outfitter, who calls her Chingachgook, another intertextual reference to The Last of the Mohicans by James Fenimore Cooper: "My friends call me Nasty, says Nathaniel Bumppo. Chingachgook is my friend. He's an Indian. But he is my friend anyway" (King 1994, 392). In a frivolous spur of racial profiling, Nasty offers a white man's perspective based on dehumanizing stereotypes, while aggrandizing the "cognitive" character of white man's 'gifts,' as well as generosity.

It is Nasty who gives Old Woman the name Hawkeye, "'a name for a white person who wants to be Indian"” (King 1994, 395), before dropping dead. Nasty Bumppo, a spin on the character of Natty Bumppo from James Fenimore Cooper's novels, finds Hawkeye a name appropriate to the stereotype of an Indian hunter. Hawkeye, a Marvel comic-book character, is an extraordinary marksman, but white. The significance of the naming-ritual, or naminggame, in the narratives told by the four Indians, draws yet another parallel between the juxtaposed Western and Indigenous ethos. Moreover, it exposes the mechanisms by which Indigenous cultures are devalued and denigrated on the basic level. By placing himself in a superior position, the colonist feels entitled to re-name that which already has emotional, cultural, political, or other value. Naming enables the colonist to appropriate and possess an object merely by assigning different values to it. By extension, the colonist transcribes the values maintained by his own tradition onto another culture, while rendering it inferior. In his article, "The Economy of Manichean Allegory," JanMohamed (2003, 23) notes that Europeans "denigrate" the Native in numerous ways, creating a fetishist representation of the Native's "moral inferiority," which in turn creates the space where Europeans are morally superior. In his moral superiority, then, the colonist enforces the Western ethos (King 1994, 392). As in the previous versions of the stories told by the Lone Ranger, Ishmael and Robinson Crusoe, with the help of Coyote and the $I$ entity, or rather against their intrusions, Old Woman is arrested for attempting to impersonate a white person, and transferred to Fort Marion. 


\section{CONCLUSION}

The stories of the four Indians - the Lone Ranger, Ishmael, Robinson Crusoe, and Hawkeye, or First Woman, Changing Woman, Thought Woman, and Old Woman - interpenetrate the narratives of the characters featuring the novel real-world of Green Grass, Running Water. More importantly, on their own, they expose the profound impact of institutionalized narratives as exercised and enforced at the social, political and cultural levels. More precisely, each of these female emanations, who have their male manifestations in the highbrow and pop-culture characters, are discounted and disregarded because of their race, gender, and ultimately, undesirable religious practice. Moreover, these elements of their dream-like narratives resurface in the real life of the characters so that the line between the fictional and factual is blurred in numerous ways.

The four Indians as the narrators of the stories of Creation still belong to the storyworld, and their interaction with other characters is not provisional. On the surface level of the novel, at which the real-world characters operate, the four Indians or four Indian women, have limited but specific functions as they influence and guide other characters, in their quest to fix the world, even unknowingly. More specifically, at the level of the satirical cosmological mishmash, these characters provide the foundation for the process of change which should begin in the novel real-world. Here, they operate at the level of general and political discourse. On the one hand, they subversively expose the metalanguage of the colonist. On the other, their stories provide a symbolic corrective language since they alter or edit the core of Western grand narratives.

In The Location of Culture, Bhabha $(1994,25)$ argues that "[t]he language of critique is effective [...] to the extent to which it overcomes the given grounds of opposition and opens a space of translation: a space of hybridity". In addition to retrieving and reclaiming Indigenous space, the language of King's four "mystics" disintegrates the binary oppositions imposed by the Western tradition, and creates a transcultural space where the Indigenous informant assumes the role of the subject, rather than the object in the so-created narrative discourse. Such a position may not imply liberation from the discourse of power in itself, but it does allow for a re-evaluation of the balance of power within the discursive reality.

The novel's circular and repetitive technique and formal structure confirm that Indigenous space is no longer possible to regard in isolation. The space envisioned in Green Grass, Running Water strives to dissolve the structures of power shaped through centuries of racial profiling and sustained by the twentieth century media and film industry which glorified aspects of colonial history. In order for political and cultural transformation to happen, the foundations of societal power must be re-examined. In addition, King's novel demystifies and discredits the inflexible and ethically doubtful nature of the JudeoChristian tradition and exposes them for the mythical constructedness used as the frame for political, economic, and other colonial aspirations. What the novel achieves is the creation of a transcultural space which emphasizes the artifice of stories as well as their discourse-producing and disseminating power. Green Grass, Running Water places characters shaped by the Judeo-Christian tradition alongside their Indigenous counterparts within a historically associative, whimsical and all-inclusive cosmologic narrative, to interrogate explicitly the authoritarian nature of narratives as assumed by discourse. At the same time, the novel provides a radical revision of narratives in the transcultural space. 


\section{REFERENCES}

Ashcroft, Bill, et al. 2007. Post-colonial Studies: The Key Concepts. $2^{\text {nd }}$ ed., Routledge.

Bailey, Sharon M. 1999. "The Arbitrary Nature of the Story: Poking Fun at Oral and Written Authority in Thomas King's "Green Grass, Running Water"." World Literature Today 73, no. 1: 43-52. doi:10.2307/40154474. Accessed April 2, 2019.

Bhabha, Homi K. 1994. The Location of Culture. London: Routledge

Cox, James H. 2000. ""All This Water Imagery Must Mean Something": Thomas King's Revisions of Narratives of Domination and Conquest in "Green Grass, Running Water"." American Indian Quarterly 24, no. 2: 21946. www.jstor.org/stable/1185872. Accessed April 2, 2019

Donaldson, Laura E. 1995. "Noah Meets Old Coyote, or Singing in the Rain: Intertextuality in Thomas King's "Green Grass, Running Water"." Studies in American Indian Literatures 7, no. 2: 27-43. www.jstor.org/stable/20736846. Accessed April 2, 2019

Frantz, Fanon. 2004. The Wretched of the Earth. New York: Grove Press.

JanMohamed, Abdul R. 2003. "The Economy of Manichean Allegory." The Post-colonial Studies Reader, Ashcroft, Bill et al, Eds. Taylor \& Francis e-Library, 18-23.

King, Thomas. 1994. Green Grass Running Water. Harper Perennial.

Kristeva, Julia. 1941. "The Bounded Text.” In Desire in Language - A Semiotic Approach to Literature and Art, edited by Leon S. Roudiez, 36-63. New York: Columbia University Press.

Lutz, John S. 2007. "Introduction" In. Myth and Memory: Rethinking Stories of Indigenous-European Contact, 1-15. University of British Columbia Press.

McMillan, Alan D, Eldon Yellowhorn. 2004. First Peoples in Canada. Vancouver: Douglas \& McIntyre.

Morton, Desmond. 1997. A Short History of Canada. McClelland \& Stewart.

Nordin, Irene G., Edfeldt, Chatarina, Hu, Lung-Lung, Jonsson, Herbert, Leblanc, André, Eds. 2015. Transcultural Identity Constructions in a Changing World. PL Academic Research.

Pratt, Mary Louise. 2008, 15 ${ }^{\text {th }}$ Edition. Imperial Eyes: Travel Writing and Transculturation. New York: Routledge, 1992

Said, Edward W. 2003, 25 ${ }^{\text {th }}$ Edition. Orientalism. Penguin Books Ltd, 1978.

Slemon, Stephen. 2003. "The Scramble for Post-colonialism.” In The Post-colonial Studies Reader, edited by Ashcroft, Bill et al, Eds. Taylor \& Francis e-Library, 45-52.

Spivak, Gayatri Chakravorty. 1999. A Critique of Postcolonial Reason. Toward a History of the Vanishing Present. Cambridge, Massachusetts: Harvard University Press.

Welsch, Wolfgang. 1999. "Transculturality - the Puzzling Form of Cultures Today." In Spaces of Culture: City, Nation, World, edited by Mike Featherstone and Scott Lash, 194-213. London: Sage.

\section{TRANSKULTURALNI PROSTOR U ROMANU SVE DOK JE TRAVA ZELENA I VODE TEKU TOMASA KINGA}

U ovom radu kroz roman Sve dok je trava zelena i vode teku (1994) Tomasa Kinga ispitujemo kontakt između dve kulture u Kanadi, i to kulture domorodaca i kulture doseljenika. Analiza transkulturalnog prostora koji je Tomas King stvorio u svom romanu se oslanja na teorijski okvir koji predstavljaju postkolonijalne studije i dela kritičara poput Stivena Slemona, Edvarda Saida, Homi Babe, Gajatri Čakravorti Spivak, i drugih. Četiri mitološke priče u romanu predstavljaju plodno tle na kome se može analizirati kontakt između dva kulturološka, društvena i politička prostora. Svrha istraživanja u ovom radu je da pruži objašnjenje prirode transkulturacije, kao i da ponudi tekstualni "hibridni prostor" (Baba, 1994: 25).

Ključne reči: Kanada, postkolonijalne studije, Prvi narodi, transkulturacija 